\title{
منهجية التعامل مع السنة النبوية
}

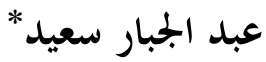

الحمد لله رب العالمين، والصلاة والسلام على أشرف الأنبياء وخاتم المرسلين سيدنا محمد وآله وصحبه والتابعين لهم بإحسان، أما بعد،

فهذا بحث حول الضوابط المنهجية في التعامل مع السيّة النبوية، ينطلق الباحث فيه من الحاجة الملحة لهذه الضوابط وأهميتها، مستعرضا جملة من أوجه الخلل في المنهجيات القائمة في التعامل مع السنّة النبوية، وسيحاول الإجابة على جملة من الأسئلة المثارة حول هذه القضية المهمة، مستندا في ذلك إلى جملة من الجهود الساقة المقدّرة في خدمة السنّة الشريفة، راجيا أن يصل هذا البحث إلى النتائج المرجوة خدمة للسنة

ولإدراك أهمية البحث في منهجية التعامل مع السنة فإننا نتوقف أمام القضايا الرئيسة التالية:

1. تعرّضت السنة النبوية منذ القدم لصور شتى من الإعتداءات ولا زالت، فمن وضع الحديث وكذبه وتحريفه قديما، إلى سوء عرضه وفصله عن مقاصد الدين وكلياته، إلى النظرة الجزئية إليه بعيدا عن القرآن وبقية السنّة، وغير ذلك من صور الإعتداء التي نراها هذه الأيام. وقد كانت اعتداءات القدماء دافعا للعلماء في حينه للدفاع عن السن النبوية، فوضعوا قواعد منهجية للدفاع عن السنة، ومايتها وتنقيتها من الوضع والكذب والتحريف، ضمن ما عرف بعلم مصطلح الحديث. واعتداءات اليوم لا تقل خطورة عن تلك، بل هي امتداد لها، ولذلك ينبغي أن ينبري العلماء والباحثون لإستئناف جهود السابقين في الدفاع عن السنة

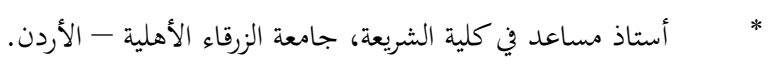

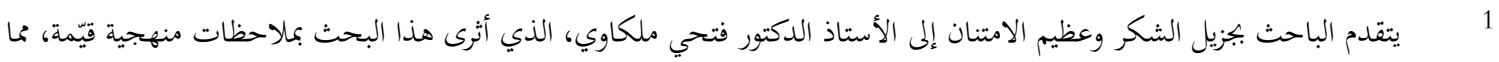

$$
\text { كان له أكبر الأثر في تحسينه وتويده، فجزاه الله عن الباحث خير الجزاء ونفع به. }
$$


النبوية، من التحريف والتشويه وإساءة العرض والفهم، وهذا البحث خطوة في هذا الطريق، ومحاولة لوضع بعض الضوابط المنهجية في التعامل مع السنة.

2. موقع السنّة من الكتاب مسألة تنازعها الآراء منذ القدم، فمن رافض الاعتماد عليها والاحتجاج هما، مكتفيا بالكتاب، كالدكتور محمد توفيق صدقي فيما نشره في مجلة المنار تحت عنوان "الإسلام هو القرآن. وحده"، إلى القائلين بتأخّر رتبة السنّة عن الكتاب في الاعتبار، كالإمام الشاطبي في الموافقات3 3 (ج4ص77)، وبعض المتأخرين كالشيخ عبد العزيز الخولي في كتابه مفتاح السنّة (ص 6، 10، 11)، إلى من قال بجعل السنّة قاضية على الكتاب وناسخة لأحكامه، كقول الأوزاعي رحمه الله: ( إن القرآن أحوج إلى

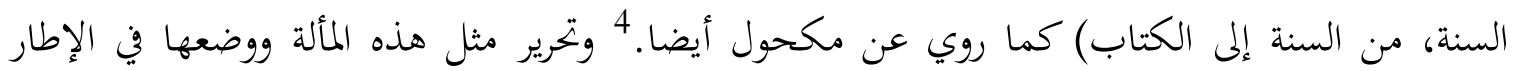
المنهجي أمر له أهمية، وسيحاول هذا ابحث فعل ذلك.

3. رغم ما وضع من قواعد علم المصطلح، وأصول نقد الحديث سندا ومتنا، فإننا نرى تجاوزا كبيرا

لهذه القواعد، إذ يكتفى في كثير من الأحيان بالنظر إلى الإسناد دون المتن، وفي معظم الأحيان يُعتمد على كتاب تقريب التهذيب لابن حجر العسقلاني في الحكم على رجال الإسناد. ويزداد هذا الإشكال وضوحا عندما يكون الراوي ممن تعارضت فيهم أقوال علماء الجرح والتعديل، فهذا باحث يوثقه ويصحح الحديث، وآخر يضعّفه ويضعِف الحديث تبعا لذلك، بل نفس الباحث قد يقع في هذا التناقض في كتابه الواحد، ولإدراك مثل هذه الأمور بمكن مراجعة مرويات علي بن زيد بن جُدعان والحكميم عليها، وفي تحقيق الشيخ أحمد شاكر رحمه الله لمسند الإمام أحمد، والسلسلة الصحيحة للشيخ ناصر الدين الألباني على سبيل المثال لا الحصر. مما يجعلنا بحاجة لإعادة التأكيد على أصول نقد الحديث وضرورة الاهتمام بالمتن إلى جانب السند، وهذا ما سيحاول الباحث أن يؤكد عليه في بحثه.

$$
\begin{aligned}
& 2 \text { 2 }
\end{aligned}
$$

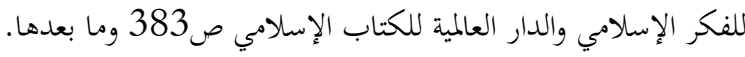

$$
\begin{aligned}
& 3
\end{aligned}
$$

4 4 انظر المصدر السابق 332، وانظر تعليق الشيخ محمد الغزالي على هذه الفكرة في بكثه المقدم لندوة "السنة النبوية ومنهجها في بناء النهاء

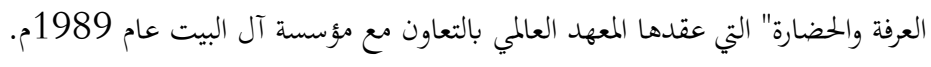


يهدف هذا البحث إلى الإجابة على الأسئلة التالية:

- ما الذي يحيد بالسنة عن أداء دورها في البناء الفكري والمعرفي للأمة؟

- كيف تتجاوز السنة دورها التشريعي إلى دور آخر فاعل في البناء المعرفي والحضاري؟

- ما مدى إمكانية إعادة قراءة السنّة وتحصيل علوم ومعارف جديدة؟

- ما الضوابط المنهجية التي نستطيع من خلالها أن نحسّن قراءة النص بعد إثباته؟

وسيحرص الباحث على الإجابة على هذه التساؤلات من خلال عرضه لمصدرية السنة، والتوقف أمام

عدد من مظاهر الحلل المنهجي في أشكال التعامل مع السنة، مع بيان الضوابط المنهجية التي يراها الباحث في التعامل مع السنة النبوية، ولكن لا بد قبل ذلك من وقفة مع الجهود السابقة ذات العلاقة بموضوع

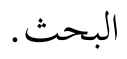

\section{جهود السابقين في العناية بالسنة والتعامل معها:}

لقد بدأ الاهتمام بالسنة مع بدء النبوة، إذ كان صحابة النبي صلى الله عليه وسلم يحرصون على متابعة ما يقوله رسول الله صلى الله عليه وسلم وما يفعله وما يقرّه، فمنهم من كان كثير الملازمة له كأبي هريرة رضي الله عنه، ومنهم من لم تتح له ظروفه ذلك، فكان يتابع أخبار النبي صلى الله عليه وسلم من خلال إخوانه من

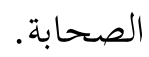

أما بعد وفاته صلى الله عليه وسلم، فقد ابته الصحابة لمعرفة ما فاتم من سنة رسول الله صلى الله عليه وسلم، وقد ظهرت الحاجة إلى الرواية واشتدت مع اتساع أقطار الإسلام وكثرة النوازل والأحداث. وانقطع كثير من الصحابة للرواية في شتى أمصار الإسلام، كابن عباس رضي الله عنهما في مكة (ت68هـ)، وابن مسعود رضي الله عنه في الكوفة (ت93ه) وغيرهم. وقد التخذ بعض الصحابة لأنفسهم منهجا في التوثق من الرواية، كطلب الشهود أو اليمين عند أبي بكر وعمر وعلي رضي الله عنهم، أو نقد المتن عند 
تعارضه مع كتاب الله، أو حديث آخر، أو مع معارض عفلي معتبر، كما كان عند عائشة رضي الله عنها، بالإضافة إلى السؤال عن سند الحديث وصدق الراوي. فلم ينته ينته عصر الصحابة حتى استقر طلب السند، ولا سيما بعد ظهور الفتن السياسية التي بدأت بمقتل عثمان رضي الله عنه. وقد استمر عصر الصحابة طوال القرن الهجري الأول، وكان آخر الصحابة موتا، محمود بن الربيع رضي الله عنه، وقد مات سنة (110هـ). وفي القرن الثاني الهجري ازدادت الحاجة إلى البحث والتحري وجمع الحديث والدراية فيه، وذلك مع توسع رواية الحديث وتشعبها، وكثرة الأسانيد، وظهور الفرق والمذاهب السياسية، فلزم التوسع في حفظ الأسانيد والمتون، ونقد الرواة ومعرفة أحواهم، وممن برع وتميز في ذلك: محمد بن مسلم بن شهاب الزهري

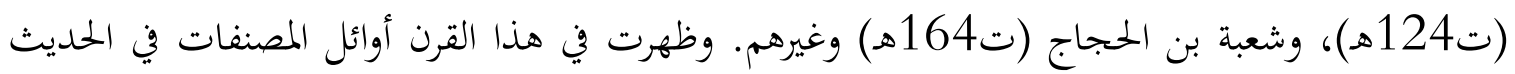
الشريف، كجامع معمر بن راشد الصنعاني، وموطأ مالك بن أنس. أما القرن الثالث الهجري فَيُعَدُّ العصر الذهبي للحديث وعلومه. ومعظم الأسماء والكتب التي نتداولها ونرجع إليها في الحديث ظهرت في هذا القرن، ومن أشهر من برز فيه؛ علي بن المديني (ت234هـ)، ويهيى بن معين (ت233هـ) والبخاري (ت256هـ)، وغيرهم من أصحاب الكتب الستة.

أما مرحلة التصنيف المنهجي والتأليف في علوم الحديث، فتمتد من القرن الرابع الهجري إلى منتصف السابع، وقد ظهرت في هذه الفترة معظم كتب علوم الحديث المشهورة التي امتازت بالأصالة المنهجية، فلم تكن مكررات عن سابقاقا، وقد حاول المؤلفون استيفاء الموضوعات عن كتبهم، ومن أوائل تلك المصنفات المحدث الفاصل بين الراوي والواعي للرامهرامزي (ت360هـ)، وهو أشمل الكتب في علوم الحديث في عصره. ومعرفة علوم الحديث للحاكم النيسابوري (ت405هـ)، وغيرها من المصنفات مما يصعب حصره في هذا المقام، كمصنفات الخطيب البغدادي (ت463هـ)، وكانت الذروة بما ألفه أبو عمرو عثمان بن الصلاح (ت643هـ) ومّمّاه علوم الحديث، وهو ما اشتهر بمقدّمة ابن الصلاح، وقد جمع فيه شتات علوم الحديث وفنونه، وما ضمّت من قواعد منهجية في الحكم على الحديث قبولا وردا، وفي أقسام السيّة وغيرها، وقد جاء هذا الكتاب متميّزا على ما سبقه من الكتب ومحتاجا إليه من لحقه من العلماء. 
وأما ما منتصف القرن السابع، فقد كان العلماء مقلدين لمن سبقهم، معتمدين على مؤلفاقم، اختصارا أو شرحا للكتب السابقة، ومعظم الكتب دارت حول كتاب ابن الصلاح "علوم الحديث"، كلتقريب للنووي، والباعث الحثيث لابن كثير، وغير ذلك مما يصعب حصره في هذا المقام، ويككن الرجوع إليه في كتاب: "الرسالة المستطرفة في بيان مشهور كتب السنة المشرفة" للكتّاني.5

أما في هذا القرن فقد برزت جملة من المؤلفات والجهود التي خدمت السنة النبوية، وحاولت أن تؤصل لمنهجية في التعامل مع السنّة، وقد تركزت هذه الجهود في المحاور الرئيسية التالية:

1. بتحيد التأليف في علوم الحديث وأصول نقده وتاريخه، واعتمادا على ما ألفه السابقون، ولكن بلغة

تلائم هذا العصر، وتسهل تقديم هذا العلم إلى طلبته، والمهتمين به، وقد اشتهر في هذا الجانب العديد من المؤلفات التي يصعب حصرها في هذا المقام، ونذكر منها على سبيل النثال: السنة ومكانتها في التشريع الإسلامي للدكتور مصطفى السباعي، 6 وعلوم الحديث ومصطلحه للدكتور صبحي الصالح، 7 ومنهج النقد في علوم الحديث للدكيور نور الدين عتر، ${ }^{8}$ وقواعد التحديث للقاسمي، 9 والسنة قبل التدوين للدكتور محمد عجاج الخطيب، 10 الفكر المنهجي عند المحدثين للدكتور همام سعيد، ${ }^{11}$ وغيرها كثير.

2. إخراج الكثير من الخطوطات إلى حيز الوجود، والعمل على تحقيقها، وقد تمحورت هذه الجهود حول كتب الرواية الصحاح والسنن، وكتب نقد الرجال وكتب علوم الحديث وغيرها، مع أن الكثير من الجهود أخذت طابعا بتحاريا، إلا أها خدمت السنة خدمة جيّدة، كما أن بعض الدراسات التي أجريت إلى جانب تحقيق هذه المخطوطات، قدمت إفادات جليلة ومنهجية في التعامل مع السنّة. وأحب أن أشيع هنا إلى كتاب ابن رجب الحنبلي شرح علل الترمذي، والدراسة التي كتبها الدكيور همام سعيد إلى جانب

$$
\begin{aligned}
& 5 \\
& 6 \text { 6 } 6 \\
& 7 \\
& 8 \\
& 9 \text { 9 } 9 \\
& 10 \\
& 11
\end{aligned}
$$


التحقيق. 12 لما لهذه الدراسة وهذا الكتاب من إضافة نوعية في إبراز معالم علم العلل إلى ساحة البحث، واستدعاء الانتباه إليه، وفي هذا العلم ما فيه من قضايا منهجية تغيب عن ساحة الباحثين، وناقدي الحديث، ولا سيّما المعاصرين منهم.

3. الدراسات الموضوعية في السنة النبوية وهذا النمط من الدراسة أسهم إساهما كبيرا، في تقديم السنة النبيوية بلغة العصر للمهتمين، فضلا عن تسهيل توظيف السنة، في خدمة المناحي الحياتية والعلوم الأخرى، التي قم الدارسين حيث بتمع هذه الدراسات الأحاديث المتعلقة بموضوع ما، وتصنفها تبعا لموضوعات الأحاديث، وتدرسها وتحكم عليها. وقد برز هذا النمط من التأليف في الرسائل الجامعية في الدراسات العليا، كالأحاديث المتعلقة بالطفل، والنصارى، والشهيد، والأمن الغذائي، والرفق، والتصوير، والبيوع، وغير ذلك برك من الموضوعات التي لا غنى للباحثين عن العودة إليها.

4. الفهارس والتصنيفات: وقد أسهمت هذه الفهارس إسهاما كبيرا في تسهيل الوصول إلى مواضع الحديث، والدلالة عليها، ولا يخفى على أحد من طلبة العلم، ما للمعجم المفهرس لألفاظ الحديث، الذي ألفه جمع من المستشرقين، من دور في خدمتهم ودلالتهم على مواطن الحديث. ولا بد في هذا المقام من الاشارة إلى مشروع موسوعة الحديث النبوي، الذي تبنته جمعية الدراسات والبحوث الاسلامية في الأردن، وقام عليه جمع من أساتذة السنة وعلوم الحديث، وقد أنجز منه الدليل التصنيفي لموضوعات السنة النبوية. وغير ذلك من الفهارس والجهود التي يصعب حصرها.

5. البرجيات الحاسوبية: وهذه البرجيات وإن أخذت في طابعها لاعام البعد التجاري أيضا، إلا أها قد خدمة كبيرة من حيث تسهيل الوصول إلى مواطن الحديث في كتب السنّة، والمعلومات المتعلقة بها إسنادا ورجالا، أو معاني وشرحا، وقد اشتهر منها: البرنامج الخاص بالكتب التسعة (موسوعة الحديث النبوي)، والموسوعة الذهبية التي صدرت مؤخرا، ومحاولات أخرى في برججة بعض الكتب الخاصة، كصحيح البخاري وغيره. ولكن هذه البرجيّات بحاجة إلى مزيد من الاهتمام والتطوير، والخروج عن إسار الكتب المؤلفة ونقلها وبرجتها، إلى الإبداع في التنفيد والتصنيف، والربط مع قواعد الاستدلال والاستنباط، وجهود الفقهاء، والعلوم 
الحديثة، وغير ذلك مما لا بد من مراعاته، ويتطلب أحيانا، بتحاوز البعد التجاري التسويقي، إلى المضمون العلمي والاضافات الإبداعية.

6. المؤترات والندوات المتعلقة بالسنّة النبوية، على المستوى المحلى والإقليمي والعالمي، ولا مجا لاستعراضها هنا، وقد كتب تقريرا حول هذه المؤتمرات، وعرّف بها، السيد محي الدين عطية. في الجزء الأول من كتاب (ندوة السنة النبوية ومنهجها في بناء المعرفة والحضارة)، التي عقدها المعهد العالمي للفكر الإسلامي، بالتعاون مع مؤسسة آل البيت في عمان عام 1989م. وما أود تركيز الإشارة إليه في هذا المجال، تلك الجهود التي يبذها المعهد العالمي للفكرالإسلامي باتحاه بلورة منهجية في التعامل مع السنة النبوية، سواء

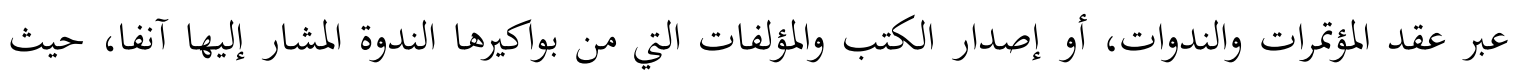
تضمنت جملة من الأبحاث المهمة في هذا المجال، منها ملخص لكتاب الشيخ محمد الغزالي- رحه الله "السنة النبوية بين أهل الفقه وأهل الحديث"، ولا يخفى ما أشاره هذا الكتاب من ردود أفعال، بالغت في الإساءة إليه دون مبرر، مما حال دون ما أراد الشيخ - رممه الله - أن يستدعي الانتباه إليه، من فصام نكد ساد بين دارسي السنة، ودارسي الفقه، نجم عنه خلل كبير في التعامل مع السنة. ومحاولة التأكيد على الحاجة للضوابط المنهجية في التعامل مع السنة، مع أنه لم يضعها، وإن حاول أن يؤكد على بعضها قليلا. ثم جاء بحث الدكتور يوسف القرضاوي بعنوان "كيف نتعامل مع السنّة، معالم وضوابط"، وقد حاول فيه أن يستكمل ما بدأه السيخ الغزالي - رمه الله - حيث وضّح جملة من الأصول والقواعد التي لا بد من مراعاقا عند التعامل مع السنّة، وقد جاءت تلك الضوابط جيّدة في عمومها، لكنها لم تكت كافية من جهة، وبعضها تفصيلي يمكن أن يندمج مع بعض الضوابط الأخرى من جهة ثانية، وقد طبع هذا البحث في كتاب مستقل تحت العنوان نفسه فيما بعد.

كما تضمّنت النّدوة جملة من الأبحاث، أكتفي بالإشارة إلى بحثين منها: أولما بحث بعنوان "السنة مصدرا للتشريع زمنهج الاحاجاج بها"، 13 للدكتور محمد سعيد رمضان البوطي حيث تعلق البحث بمنهج الاحاجاج فقط، واكتفى بالاشارة فيه إلى تصنيف تصرفات النبي صلى الله عليه وسلم وأفعاله، لم يتعرض 
لمنهج الفهم أو أية ضوابط أخرى في الاحتجاج. وبث آخر بعنوان "قواعد الاستدلال بالسنّة وضوابطه وطرقه"، للسيد عبد الهادي بو طالب. 14 ولم يتعرض فيه لمنهج الفهم أيضا.

وأشير في هذا القام إلى ورقة عمل أدعها الدكتور طه العلواني بعنوان (منهجية التعامل مع السنة)، ركّز فيها على أهمية نفد المتن واسعراض قواعده، كما توقف أمام بعض الضوابط المنهجية، والقراءة المفاهمية للسنة، ودور العلوم الاجتماعية والإنسانية في التعامل مع السنة والجمع بين القراءتين (الوحي والكون)، والورقة جيّدة في باجها، وقد أقدن منها وتوسّعت زيادة عليها، إذ إنها لم تسنوف الضوابط. 15 ويؤكد الباحث هنا، أن بحثه هذا يندرج في سياق الاهتمام من قبل المعهد، وأنه بناء على جهد كل من سبق، وليس منبتا عنه.

ويود الباحث إلى أن يشير أن معظم الجهود السابقة، منصبة على الاسناد وخدمته، وقلّ منها ما اهتم بالمتن وقواعده وأصول نقده، رغم إصرار البعض ومنهم الشيخ عز الدين الخطيب التميمي على نفي ذلك، 16 ويرى الباحث أن من بواكير الاهتمام بالمتن في دراسات مستقلة قائمة بذاها، كتاب "المنار المنيف" لابن قيم الجوزية، 17 ودراسات أخرى سيشير إليها الباحث في طيّ بحثه هذا لاحقا. وهذا لا ينفي أن العلماء اهتموا بالمتن عبر قواعد مصطلح الحديث، لكن ما يود أن يؤكده الباحث أنه لا بجال للمقارنة بين حجم الدراسات المهتمة بالسند ونقده، والدراسات المهتمة بالمتن ونقده، ويرى الباحث أن هذا الباب بحاجة إلى إهتمام خاص لا يتسع له هذا البحث.

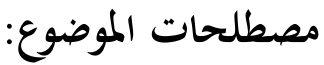

ونهن بصدد منهجية التعامل مع السنة فما المراد بالمنهجية، وما المقصود بالتعامل، وماذا نعني بالسنّة.

$$
\begin{aligned}
& 14 \\
& 16 \text { } 15
\end{aligned}
$$

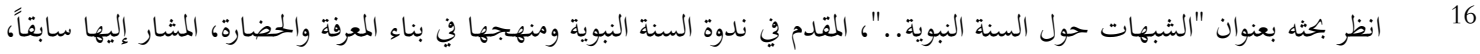

$$
\begin{aligned}
& \text { ص573-578. } \\
& \text { ابن قيم الجوزية، المنار المنيف في الصحيح والضعيف، مكتب المطبوعات الإسلامية، حلب تحقيق عبد الفتاح أبوغدة. }
\end{aligned}
$$


قال ابن منظور: "طريقُ فج: بيّن واضح، ومنهج الطريق: وضحُة، والمنهاج كالمنهج، وفي التنزيل:

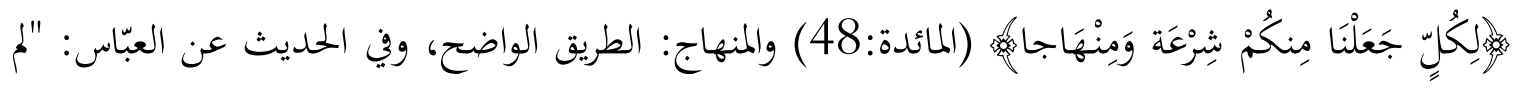
يمت رسول الله صلى الله عليه وسلم حتى تركمم على طريق ناهجة، أي واضحة بينة. وأفج الطريق: أي وضح واستبان، وصار فها واضحا بينا". 18

والمنهجية كما يراها د. نصر عارف هي: "العلم الذي يدرس كيفية تكوين المناهج وتطورها وتشغيلها،

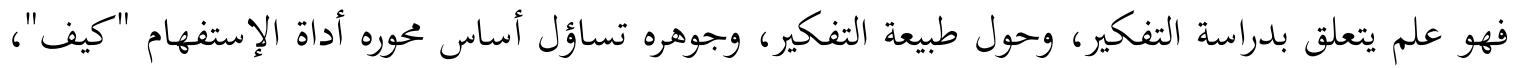
وليس ماذا وملماذا وأين ...الخ. فهو ينشغل بمناقشة الكيفية التي يمكن من خلالها الوصول إلى الفهم الأقرب للصحة لحقائق الكون والإنسان والوجود". 19 كما أشارت د. منى أبو الفضل إلى أن المنهاجية: علم بيان الطريق، والوقوف على الخطوات أو الوسائط والوسائل التي يتحقق بما الوصول إلى الغاية، على أفضل وأكمل

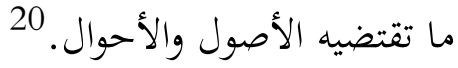

هذا مفهوم المنهجية بشكل عام، وهو -كما نرى- ذو صلة وارتباط بالدلالة اللغوية للكلمة، فالكيفية التي يتحقق بما الوصول إلى الغاية، لا يككن أن تكون إلا موضحة للطريق وكيفية السير به. أما عن المنهجية وارتباط هذا المفهوم بالسنة، فنحن نتحدث عن أفضل الوسائط والسبل والضوابط التي يمكن من خلالما الوصول إلى أحسن فهم وعرض وتنزيل للسنة النبوية، منزل الواقع والتطبيق.

أما مدلول كلمة التعامل هنا، فإننا لا نقصد به من يقصد السنة لأخذ حكم شرعي، أو درس وعبرة فحسب، وإنما نضيف إليه من ييحث في السنة لغرض الحكم على صحتها أو عدمه، ومن يحاول فهم السنة

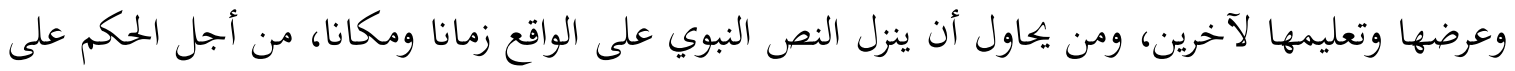
المعارف الإنسانية، والحصول على معارف جديدة، تسهم في بناء الحضارة الإنسانية وتوجهها وترشدها.

$$
\begin{aligned}
& 18 \\
& 19
\end{aligned}
$$

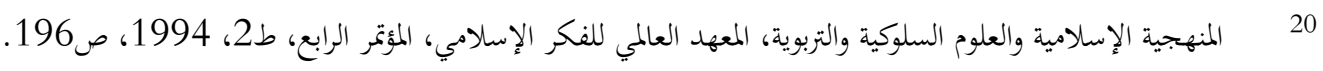


فكل هؤلاء داخلون في دائرة التعامل مع السنة، ومعنيون بسلوك أفضل السبل لتحقيق غاياتم ومقاصدهم في ضوء مقصد الشريعة وغايتها.

أما السنة: فهي ما روي عن النبي صلى الله عليه وسلم من قول أو فعل أو تقرير، وهي دالة على لفظ الحديث النبوي في حال ورود أحدهما دون الآخر، أما في حال التغاير، وإن ورد اللفظان مقترنين، فإن الحديث يزيد على السنة بما وصف به النبي صلى الله عليه وسلم، خَلقا أو خُلقا، وهو ما يشير إليه بعضهم باختلاف تعريف السنة بين المحدثين والأصوليين. 21

\section{المبحث الأول :مصدرية السنة}

لقد اشتهر بين المفكرين والعلماء أن السنة النبوية تعد المصدر التالي للقرآن الكريم، وهي المصدر الثاني للتشريع، وقد أشار كثيرون إلى أهمية السنة في فهم القرآن الكريم، وشَرْح معانيه وتفصيل مجمله، وتقييد مطلقه وتخصيص عمومه، وغير ذلك من أوجه العلاقة الوطيدة بين الكتاب والسنة. وقد تفاوتت مواقف الناس من السنة باعتبارها مصدرا للتشريع وكان من بينهم فئتان: فئة تريد أن تجعل من كل مل ورد في السنة تشريعا ملزما لكل الناس، في كل الأزمان وفي كل الأقطار، وفي كل الأحوال، مع أن فيها ما صدر عن الجبلية، وما صدر عن العادة، وما صدر عن التجربة. أما الفئة الثانية فإها تريد أن تعزل السنة عن شؤون الحياة العملية كلها، فالعادات والمعاملات وشؤون الإقتصاد والسياسة ...إلخ، يجب أن تترك للناس، ولا تدخل السنة فيها، آمرة ولا ناهية، ولا موجهة ولا هادية.

وبالإجمال فإن من السنة النبوية المنقولة إلينا، ما لا يدخل في باب التشريع، وإنما هو من أمر دنيانا المض الذي ترك تدبيره وتنظيمه إلى عقولنا واجتهادنا، كما أن منها ما لا يحمل صفة التشريع العام المطلق الدائم الذي يخاطب الناس في كل زمان ومكان، على أنه لا بد من التنبيه على ضرورة التدقيق وشدة التحري

$$
21 \text { ا انظر: مصطفى السباعي، السنة ومكانتها في التشريع الإسلامي، بيروت المكتب الإسلامي: ط2، 1978، ص47. }
$$


في التمييز بين ما جاء في السنة للتشريع، وما لم يجيء للتشريع، وما كان للتشريع العام المطلق الدائم، أو ما

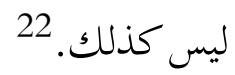

وكما أن السنة مصدرا للتشريع فإها مصدر لمجموعة من المعارف، وهي الشق الثاني للوحي، بعد القرأن كما أسلفنا، وكما نعتقد أن للقرآن الكريم دورا أساسا في البعث الحضاري والمعرفي للأمة، فإننا نعتقد أن هذا الدور المحوري يمتد للشق الثاني من الوحي للسنة؛" فالسنة هي المنهج النبوي النظري والعملي الذي جسد البلاغ القرآي، وأحال كلمات الله واقعا وحضارة يحياها الناس الذين آمنوا بهذا البلاغ، ومن هنا تأتي مكانتها مصدرا للمعرفة تستمد صدقها.

والسنة النبوية ليست فقط مصدرا للمعارف الدينية بكل ما تشمله هذه التسمية مما يتعلق بعالم الغيب أو عالم الشهادة، سواء في الأخبار عما مضى أو ما يستقبل، أو ما يحتاجه الناس لقضايا يعايشوها، وإنام هي مصدر للمعارف عموما، بما تتضمن من أخبار وإنشاءات، سواء فيما يتعلق بالتربية أو الصحة أو البيئة أو الاقتصاد. ${ }^{24}$ ويمننا لنا أن نشير إلى بعض المعارف التي يمكن تحصيلها من السنة النبوية ومنها: أ- أسباب نزول البلاغ القرآي والوحي الإلهي على رسول الله صلى الله عليه وسلم. ب- التاريخ السياسي والاجتماعي والاقتصادي والحربي والأدبي للتجربة الإسلامية في عصر صدر

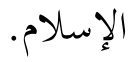
ج- الفروع التي وقف القرآن عند أصولها، ومنها نتعلم التمييز بين الثوابت والمبادئ والأركان والأصول، وبين الفروع والمتغيرات التي تقوم وتنمو وتتجدد على هذه القواعد والأصول، مرتبطة بها، ومصطبغة بصبغتها، وفي الوقت ذاته مظللة بمساحات جديدة من الوقائع و المشكلات.

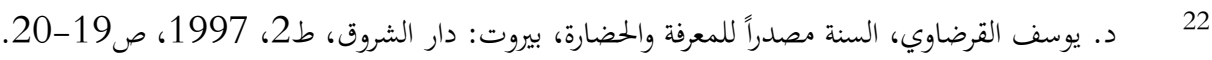

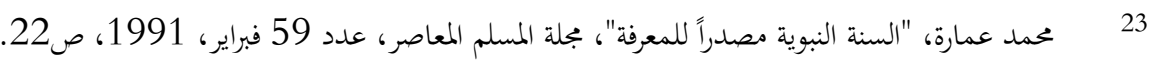

$$
\begin{aligned}
& 24
\end{aligned}
$$


هـ- التشريع النبوي التراث القانوني في السنة، سوار ما كان فيه التفصيل لمجمل القرآن، أو ما كان فيه اجتهاد فيما لا وحي فيه، وهي كذلك المصدر للتمييز في هذا الاجتهاد النبوي بين ما أقره الوحي بالنص عليه أو بالسكوت عنه، وبين ما نزل الوحي مصوبا له أو معدلا.

و - التمييز في المماؤسات النبوية بين الدين الثابت الذي يجب فيه الاتباع للمنطق والمفهوم، وبين المتغيرات الدنيوية التي يجب فيها التزام المقاصد، دون حرفية التطبيقات والتمييز أيضا بين الدين الثابت والمتغير من الأعراف والعادات.

ز- التمييز بين ما لا يستقل العقل بإدراكه - من حيث الحسن والقبح - في التشريع والأحكام

والفرائض والشعائر، وكيفية الجزاء ومقادير الثواب والعقاب، وبين ما هو من شؤون الدنيا الموكولة إلى عقول البشر، لقدرة هذه العقول على أن تستقل بإدراكها - حسنا وقبحا - وعلى أن تقنن لها إطار شرع الله. 25

\section{المبحث الثاني :مظاهر الخلل في التعامل مع السنة}

ولإدراك أهمية البحث في منهجية التعامل مع السنة فإننا سنتوقف أما بعض مظاهر الخلل المنهجي في

التعامل مeهـا

1- الفصل بين أجزاء الوحي ومفرداته: وهذا الخلل متعلق بالقرآن من جهة، ومتعلق بالسنة من

جهة أخرى، ووجه تعلقه بالسنة متعدد الجوانب، فمن جانب الفصل بين السنة والقرآن إلى الفصل بين

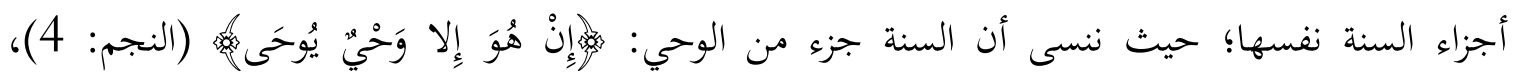

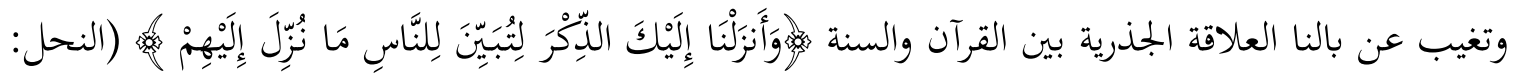
44)، وهذا إما لغفلة عن طبيعة العلاقة بين السنة والقرآن، وإما لسوء فهم ناجم عن الحرص على السنة والدفاع عنها، إلى أنْ غدن في أذهاننا مقدمة على القرآن في الاستدلال والفهم، حتى إن أحدنا ليتحدث بالحديث ساعة من الزمان، أو يكتب الصفحات العديدة فيكثر الاستلال بالسنة، ويسرد الحديث تلو 
الآخر، ولا يستدل إلا بالقليل من الآيات، ويأتي هما متأخرة، وهذا تقديم للفرع على الأصل، هذا من جهة. ومن جهة أخرى فإنه يغيب عنا أيضا، أن الترابط بين عناصر السنة، وانسجامها وعدم تعارضها، من باب أولى، ومن تََّّ السنة، بمعنى أن ينتقى حيث في مسألة ما دون بقية الأحاديث ويتم فهمه وتفسيره بشكل جزئي، يختلف في دلالاته عما لو أخذ معه جملة أخرى من النصوص ذات العلاقة، ومثال هذه الجزئية من الفهم والتفسير، الاستناد إلى قول رسول الله صلى الله عليه وسلم،: "ما أسفل الكعبين من الإزار فهو في النار".26 ومعناه: "ما كان دون الكعبين من قدم صاحب الإزار المسبل فهو في النار عقوبة له على فعله، فكنّى بالثوب عن بدن لابسه". 27 في الانكار الشديد على من لم يقصر ثوبه، دون ما رواه البخاري في موضع آخر من قول رسول الله صلى الله عليه وسلم: "من جر ثوبه خيلاء، لم ينظر الله إليه يوم القيامة، قال أبو بكر: يا رسول الله، إن أحد شقي إزاري يسترخي، إلا أن أتعاهد ذلك منه، قال النبي صلى الله عليه

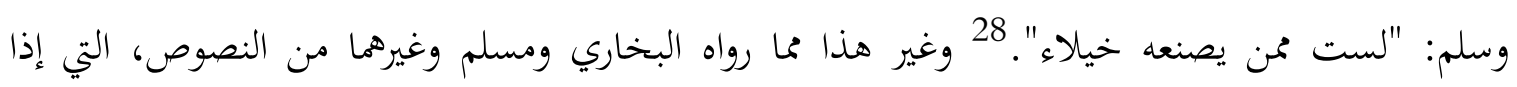

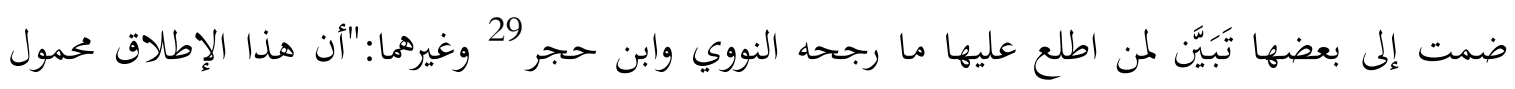
على ما ورد من قبل (الخيلاء) فهو الذي ورد فيه الوعيد".

2- الفصل بين قراءة السنة وقراءة الكون: حيث لا يُنتبه إلى أنه ينبغي أن يكون هناك توافق بين السنة، وسنن الله في الكون، كما ينبغي أن يكون ذلك بين القرآن والكون، فنجد أن بعض الروايات تتسرب من هنا وهناك، دون أن يتم التدقيق في مدى إنسجامها وتوافقها مع نواميس الكون وقوانينه، ومن ومن ذلك مثلا ما روي من " أن الله رد الشمس بعد غروبها لعلي إلى العصر - كما ردها ليوشع بن نون - حتى صلى العصر". 30 فالجمع بين الروايتين يحول دون تناقل مثل هذه المرويات، أو على الأقل يجعلنا نتوقف أمامها متسائلين، ولا نكتفي بصحة السند للححكم بصحة الحديث.

$$
\begin{aligned}
& 26 \text { ـ البخاري. صحيح البخاري مع فتح الباري، بيروت: دار المعرفة، كتاب اللباس: باب ما أسفل من الكعبين فهو في النار رقم 587، } \\
& \text { ج15، ص256. }
\end{aligned}
$$

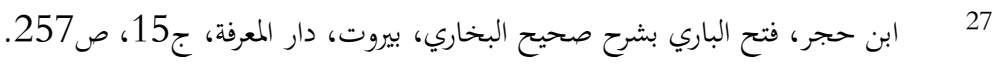

$$
\begin{aligned}
& 28 \text { 2 } 28
\end{aligned}
$$

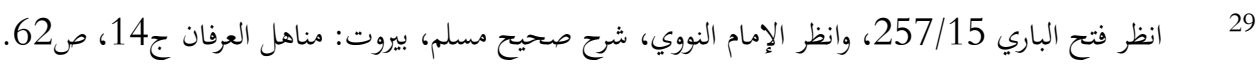

$$
\begin{aligned}
& 30 \text { } 30
\end{aligned}
$$




\section{3- الفصل بين السنة والؤية الكلية الشمولية المقاصدية للشريعة الاسلامية:}

ولا يخفى لفهم السنة وتفسيرها وروايتها، بعيدا عن مقاصد الشريعة وغاياتها من آثار سلبية، ذلك بأنّ الفهم الظاهري الحريف للنصوص سيكون هو السائد الطاغي، وهذا سيوقع الماس في الحرج ويضيّق عليهم، ولا

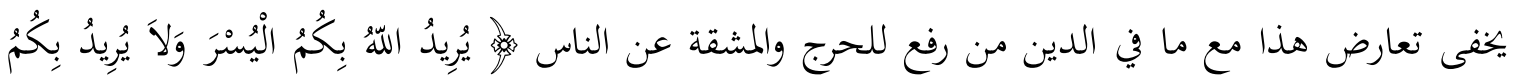

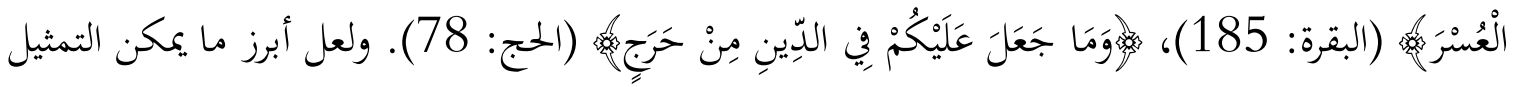
به في مثل هذا الموقف، الإصرار على الفهم الظاهري لقول أبي سعيد الخدري رضي الله عنه: "كنا نخرج الزكاة إذا كانت فينا رسول الله صلى الله عليه وسلم صاعا من طعام، أو صاعا من شعير، أو صاعا من تمر، أو صاعا من أقط، أو صاعا من زبيب". 31

حيث التوقف أمام ظاهر النص، والقول بأنه لا يجوز إخراج صدقة الفطر من غير هذه الأصناف، وهذا القول - وإن قال به الإمام أحمد وأتباعه ورفضوا معرضة السنة بالرأي - قد يعرض مقصد الشريعة، من تحقيق مصلحة الفقير وسد حاجاته، وتيسير أمر الصدقة على من أراد إخراجها، وهذا ربما يكون واضحا في كثير من بلاد المسلمين في زماننا هذا أو في العديد من الدول الاسلامية، ولعل الأقرب لتحقيق هذا المقصد ما قال به الإمام أبو حنيفة وأصحابه، وهو قول عمر بن عبد العزيز وغيره من فقهاء السلف حيث لاحظوا أن المقصد، هو إغناء الفقراء والمساكين عن السؤال والطواف في هذا اليوم، وإشراكهم فرحة العيد، وهذا يتحقق بدفع القيمة أكثر من دفع الأطعمة العينية ليتصرف فيها حسب حاجاته. 32

\section{4- عدم التمييز بين ما كان من السنة محل التشريع، وما لم يكن:}

وقد سبق أن أشرنا إلى إنكار أن يكون شيئا من السنة ليس محلا للتشريع، مع أن المتأمل لحديث تأبير النخل وقول النبي للأنصار، أنتم أعلم بأمور دنياكم، يعلم بشكل واضح أن في حياة النبي صلى الله عليه وسلم من شؤون الدنيا ومعارفها، ما يتساوى فيه مع سائر البشر، فأيما حديث صح في الطب وصفا للعلاج،

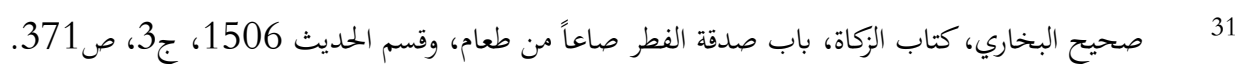
32 
أو في الزراعة في كيفيتها وأشكالها، فليس محلا للتشريع، ولا يعد ملزما للناس، وإإنما لهم أن يستأنسوا به على أن يحسن التعامل معه، كحديث الحبة السوداء مثلا، وغيره. 33

5- التسرع في رد الأحاديث: فكما أن من مناهج الخلل المنهجي في التعامل مع السنة المشرفة،

اجتزاء الحديث من بين النصوص ذات العلاقة، وفهمه فهما جزئيا، كذلك التسرع في رد الأحاديث، لمجرد أن معنى الحديث - لأول وهلة - لا يلقى قبولا في النفس، تارة بحجة مخالفته للعقل، وأخرى بحجة مخالفته لظاهر آية، وثالثة بحجة يخالفته لحديث آخر، وتارة بحجة أنه خبر آحاد لا يحتج به في العقائد، وغير هذا من الأوجه التي يستند إليها عند رد الأحاديث، ونحن لا نرفض أن يرد الحديث لسبب علمي موضوعي ومنهجي، ولكننا نرفض التسرع والمبادرة للرد، قبل التأكد من إمكانية الصحة وإمكانية إعمال النص وقبوله، واحتمال التوفيق - دون تعسف - بينه وبين ما توهّمنا تعارضه معه، بحمله على المجاز مثلا أو غير ذلك من أجه التوفيق. ومن ذلك ردهم لحديث "اللهم أحيني مسكينا، وأمتني مسكينا، واحشرين في زمرة المساكين" وهو صحيح من طريق أبي سعيد الخدري وعبادة ابن الصامت، 34 فيرده لأنه فهم من المسكنة الفقر من المال، والحاجة إلى الناس. وهذا ينافي استعاذة النبي صلى الله عليه وسلم من فتنة الفقر، وسؤاله الله تعالى العفاف والغنى، وينافي نصوصا أخرى منها قوله لسعد إن الله يحب العبد الغني التقي الخفي، والحق أن المسكنة هنا لا يراد بها الفقر، كيف وقد استعاذ بالله منه، وقرنه بالكفر: "اللهم إي أعوذ بك من الكفر

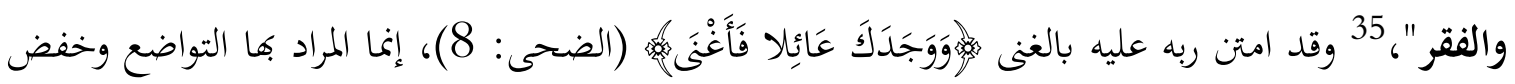
الجناح، قال العلامة ابن الأثي: "أراد به التواضع والإخبات وألا يكون من الجبارين المتكبرين وهكذا عاش النبي صلى الله عليه وسلم".

6- عدم استكمال شروط نقد الرواية: من المالحظ أن علماء الحديث حددوا شروطا لقبول الرواية، متعلقة بالسند كما أهما متعلة بالمتن، سواء فيما يتعلق باتصال السند وعدالة الرواة وضبطهم من حيث النوع

$$
33
$$

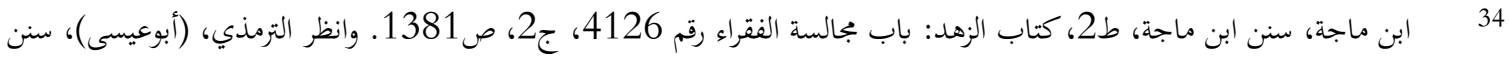

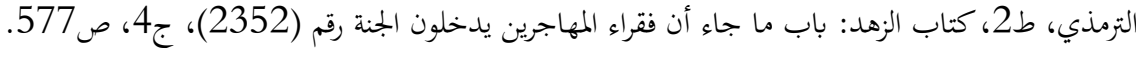

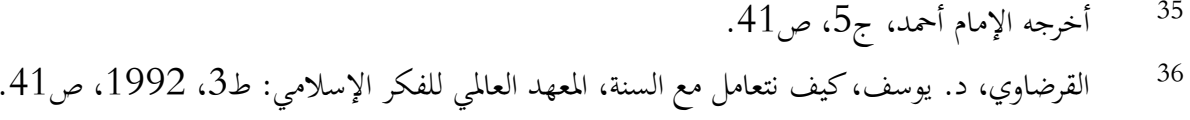


والمضمون. ومما يؤسف له أن هذا الحنلل المنهجي لا يزال مستمرا، حيث يكتفي بصحة السند أو حسنه ليحكم على الحديث كله بالصحة أو بالحسن، فيصبح مقبولا، ويعدّ دينا يتعبد به، والويل لمن خالفه مع أن الحديث ربما يكون شاذا أو معللا في إسناده، أو في متنه. ولعل السبب الأساس وراء هذا الخلل المنهجي قصر باع المعاصرين في علم العلل، الذي هو أدق علوم الحديث. والحديث المعلل كما عرفه العلماء: "ما اطلع فيه بعد التفتيش على علة تقدح في صحته مع أن الظاهر سلامته منها". 37 7- الفصل بين الفقه والحديث: حيث شاع تصور بعدم حاجة كل منهما للآخر بحجة أن دور المحدث أن ينقل النص ويثبت صحته، ودور الفقيه أن يفهمه ويستنبط منه الأحكام، والحجة في ذلك ما روي عن النبي صلى الله عليه وسلم "نضر الله امرأ سمع منا حديثا فحفظه حتى يبلغه فرب حامل فقه إلى من هو أفقه منه ورب حامل فقه ليس بفقيه"، 38 ولعل هذا الفهم لهذا الحيث بحد ذاته محل إشكال، فإن الحديث إنما طلب تبليغ حديث رسول الله صلى الله عليه وسلم والتأكيد على أهمية نشر الرسالة، كما أننا إذا قبلناه في المحدث الراوي - ناقل الحديث-، فإننا لا نقبله في المحدث الدارس للحديث ليحكم على صحته أو ضعفه، ذلك أن من مهمات الدارس أن يجكم على الحديث سندا ومتنا، ولا يستطيع أن يحكم على متن الحديث من لم يفقه ويفهم معناه، لارتباط هذا الأمر بفنون أخرى متعددة من أهمها علم مختلف الحديث، ونقد المتن لشذوذ أو علة أو نحو ذلك، ولا يكون هذا إلا لفقيه. كما أن الفقيه لا يستغني عن الحديث، إذ جل أحكان الفقه ثابتة بالسنة، "وهذا أمر لاحظه علماؤنا السابقون ونددوا بمن أهمله"، حتى روي عن بعض الأعلام مثل سفيان بن عيينة أنه قال: "لو كان الأمر بيدنا لضربنا بالجريد كل محدث لا يشتغل بالفقه، وكل

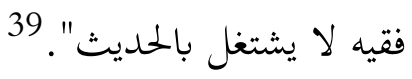

صحيح أن قدامى الفقهاء رغم اهتمامهم بالسنة، تضمنت كتبهم الصحيح والضعيف والموضوع كذلك، ولكن قدامى المحدثين تفاعلوا إيجابيا مع ذلك وألفوا كتب الحديث التي خرّجوا فيها أحاديث كتب

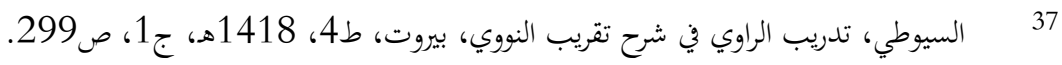

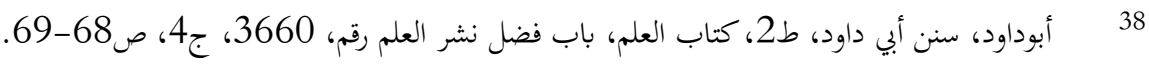

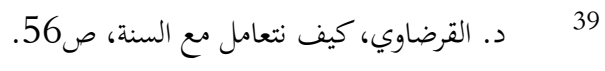


الفقه، وبيّنوا صحيحها من سقيمها كالزيلعي في كتابه "نصب الراية لأحاديث المداية"، 40 ت (764هـ)، و"تلخيص الحبير" 41 لابن حجر ت (582هـ). وغيرهما، ومن أمثلة ذلك ما روي في المسح على الجبيرة، فجميع الروايات ضعاف، قال البيهقي في السنن الكبرى: "ولا يثبت عن النبي صلى الله عليه وسلم في هذا الباب شيء". 42 ومع ذلك فقد وردت هذه الأحاديث في كتب الفقهاء وبنيت عليها أحكام.

إننا نرى اليوم من الفقهاء من يقع في الأخطاء المنهجية التي أشرنا إليها آنفا في التعامل مع السنة، وهذا لقصر باعهم في الحديث، ونرى من المحدثين من يتنطع للفتوى ويقوم بدور الفقيه، فنرى فتاواه تقف عند ظاهر النص ولا تلج في روحه ومقصده، وما الذي نسمعه من فتاوى في التصوير واللباس، وخروج المرأة ومشاركتها في الحياة العامة، ولا سيّما السياسية منها، وحرماغا هذه الحقوق، كالفتوى التي نشرت في الصحف وأصدرها الشيخ عبد العزيز بن باز -رحمه الله- باعتبار خروج المرأة من بيتها زينة محرّة، ليس ذلك إلا مؤشرا من مؤشرات الخلل في الفصل بين الحديث والفقه. فمن الواضح أننا نريد أن نؤكد على حاجة المحدث للفقه وحاجة القيه للحديث، وليس مقصدنا أبدا أن ننع كلا من الطرفين من الاشتغال في مجال الآخر، وإنما غرضنا أن يتعمق كل منهما في مجال الآخر، أو على الأقل أن يتعاونا بينهما في عقل جمعي مؤسسي، يسدد ويقارب في إخراج الأحكام واستنباطها من أدلتها الصحيحة بما يحقق غايات الشريعة ومقاصدها.

\section{المبحث الثالث :ضوابط منهجية في التعامل مع السنة}

الضابط الأول: التوثق من الحديث سندا ومتنا وفق القواعد والثروط الخحدةمن قبل العلماء

$$
\begin{aligned}
& 40 \text { 40 } 40 \\
& 41 \\
& 42
\end{aligned}
$$


ولسنا هنا بصدد التفصيل في جميع شروط توثيق الحديث والحكم عليه، بل نكتفي بما ذكره العلماء من أن الحديث الصحيح، ما اتصل سنده بنقل العدل الضابط عن مثله إلى منتهاه، ولا يكون شاذا ولا معللا، والحديث الحسن على المشهور، ما كان ضبط رواته أو بعضهم أقل من رواة الصحيح. 43 وما نود الإشارة إليه هنا، أن الناظر في شروط قبول الحديث يجدها مرتبطة بالسند والمتن معا، والغريب في الأمر أن التركيز كبير جدا، عبر تاريخ علوم السنة على شروط الإسناد وما يتعلق بها من علوم، فكان علم رجال الحديث، وكان علم الجرح والتعديل، وكانت قواعد المصطلح في غالبها منصبة على الإسناد ورواته، قد نفهم الاهتمام بالسند بشكل يزيد قليلا عن المتن لبعض الاعتبارات، لكننا لا نستطيع أن نفهم هذا التضخم العجيب في علوم السند والرواة، والضمور إلى درجة الفناء في نقد المتن والتعامل معه. 44 ولعل مجرد المقارنة بين ما ألف في خدمة الإسناد ونقده وما ألف في نقد المتن المتن كفيلة بإبراز وجه الخلل. هذا إلى جانب ما أشرنا إليه سابقا من خلل منهجي بالاكتفاء في الحكم على الحديث من خلال اسناده فقط.

وما أود التفصيل بشأنه في هذا المقام، الجزء الذي أعتقد أنه يغيب عن كثير من الباحثين في الحكم على الأحاديث، وهو ما يتعلق بشروط ثلاثة هي: التأكد من عدم شذوذ الحديث، والتأكد من خلو الحديث من علل الإسناد، والتأكد من خلو

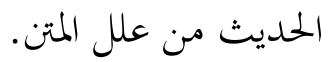
وفيما يلي توضيح هذه الشروط الثلاثة التفصيلية التس لا بد منها لصحة الحديث: التأكد من عدم شذوذ الحديث

$$
\text { 43 } 43
$$

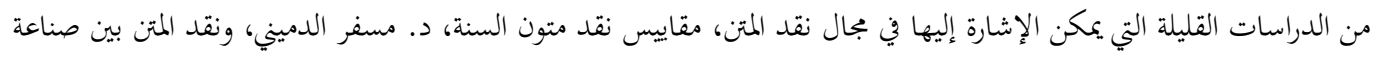

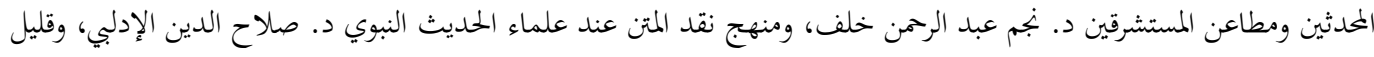

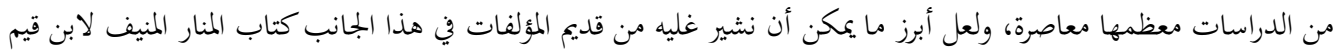
الجوزية، تحقيق الشيخ عبد الفتاح أبوغدة رمه الله. 
والحديث الشاذ كما عرفه علماء الحديث ما رواه الثقة (الفرد) مخالفا، لمن هو أوثق منه، أو لجماعة من الثقات. ومنها الزيادة في المتن، أو القلب، أو الاضطراب، أو التصحيف، أو الإدراج. 45 وهذا التعريف فيه خير دلالة على أهمية خلو الحديث من الشذوذ، ولا سيّما أننا نتحدث عن مخالفة، صحيح أن هذا الراوي المخالف ثقة، لكنه إما فرد خالف بجموعة من الثقات، ورواية الجمع أوثق من رواية الفرد، وإما خالف من كان أوثق منه وأضبط في الرواية ولهذا ينبغي أن تقدم رواية الأوثق، وهذا يؤكد أيما تأكيد، ضرورة أن لايتوقف الباحث عن حكم الحديث عند صحة إسناده، وإنما ينبغي أن يتجاوزه إلى المتن، وقد انتهج المحدثون لمعرفة هذه العيوب طريقين:

الطريق الأولى هي جمع طرق الحديث وألفاظه المختلفة، والمقارنة بينها، لتتضح موافقته لألفاظ الحديث في الطرق الأخرى فتقبل، أو مخالفته لها فترد. أما الطريق الثانية فهي الاطلاع على أقوال أهل الشأن حول ذلك الحديث، في كتب علل الحديث أو شروحه وغيرها. 46

وهذه السبل كفيلة بكشف أية زيادة أو قلب أو اضطراب أو تصحيف أ إدراج حصل في المتن، وليس هذا مقام استعراض أوجه الشذوذ هذه وأمثلتها، 47 ولكننا نود التأكيد على ضرورة خلو الحديث منها حتى نحكم بصحته.

\section{التأكد من خلو الحمديث من علل الإسناد}

والأمر الذي أود الإشارة إليه في هذا المقام، أننا ونحن نتحدث عن علل الإسناد وعلل المتن، فإننا لا نتحدث عن خلل ظاهر في الحديث، وإنما نتحدث عن علة لا تنكشف إلا للحاذق الماهر، وبعد تفتيش وبحث دقيقين، ولعل هذا هو السر وراء تخلي الكثير من الباحثين عن التفتيش وراء هذه العلل، وعدم

$$
\begin{aligned}
45 \\
46
\end{aligned}
$$


الإكتفاء بظاهر صحة السند والمتن، ولذلك كان الحديث المعلل "ما اطلع فيه بعد البحث والتفنيش على علة تقتدح في صحته، مع أن الظاهر سلامته منها". 48 أما أبرز علل الإسناد فهي:49

1- إبطال السماع الصريح، أو نفي السماع المتوهم بالعنعنة، ومثاله ما نقله ابن رجب أن أحمد قال: "البهي ما أراه سمع عن عائشة، إنما يروي عن عروة عن عائشة، رغم أنه يقول في حديث زائدة، عن السدّي حدثني عائشة".

2- إبدال الإسناد كله أو بعضه، وقد يكون من أسبابه سبق اللسان إلى الأسانيد المشهورة، فكل حديث يروى عن مالك، قد يسبق اللسان فيه إلى نافع عن ابن عمر، وفي واقع الأمر يكون مالك قد رواه

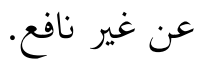

3- الوهم في رفع الموقوف، أو وصل المرسل أو ما فيه انقطاع. فقد يروى الحديث مرفوعا ولكن النّقاد يكشفون عن وهم في رفعه، ويثبتون أن وقفه أصح، وقد يروى الحديث متصلا، وإرساله أثبت وآكد، أو قد يروى متصلا وهو في الحقيقة معضل أو منقطع.

4- جمع الشيوخ وبقاء اللفظ واحدا: فالأصل أن يوجد بعض الاختلاف في روايات الحديث الواحد، لتصرف الرواة في لفظ الحديث، دون المعنى، فإذا روى أحد من الرواة حديثا واحدا عن عدد من الشيوخ ثم ساق اللفظ سياقا واحدا، فإن هذا دليل على الوهم والخطأ، إلا أن يكون الراوي مبرّزا في الحفظ جدا. وممن وقع في هذا حماد بن سلمة بن دينار البصري.

5- جرح الراوي، وليس المقصود بهذا وجود الراوي المجروج في الاسناد، فإن هذا ليس من علم العلل، لأن الاسناد به يكون ضعيفا، وميدان العلل، الحديث الصحيح. وإنما المقصود أن يروي الثقة عن راوٍ مجروح، 
فيلتبس على الناس حال المجروح، فيكشف أمره عالم العلل. فمن المعلوم مثلا أن مالكا لا يروي إلا عن الثقة، ولكنه حدث عن عبد الكريم بن أبي أمية وهو متروك الحديث. التأكد من خلو الحديث من علل المتن:

$$
\text { ومن أبرزها: }
$$

1- إحالة معنى الحديث، إذا كان راويه غير عالم باللغة ولا بالنراد من اللفظ.

2- ما كانت علته تحريفا في لفظ من ألفاظه، ومن أمثلته من حرف كلمة "نؤديه" فجعلها "نورثه" وبدل أن يجعل الحديث في صدقة الفطر، وهو كنا نؤديه على عهد رسول الله صلى الله عليه وسلم، قال: الجد.

3- ما كانت علته مخالفة روايه لمقتضاه، ومنه أحاديث أبي هريرة في المسح على الخفين، ضعفها مسلم وأحمد وغير واحد، وقال أحمد: أبو هريرة ينكر المسح على الخفين، فلا فلا يصح له فيه رواية. 4- ما كانت علته إدراج كلام آخر فيه، وهذه علة عَدّها بعضهم ضريا من ضروب الشذوذ في الحديث كما سبقت الاشارة إليه آنفا.

5- ما كانت علته أنه لا يشبه كلام النبي صلى الله عليه وسلم ومن ذلك ما يشبه كلام القصاص.

ولعل التوقف أمام هذه العلل في السند والمتن، يجعلنا ندرك مدى أهمية التوثق من صحة الحديث وسبر غوره جيدا من قبل أهل الاختصاص، قبا أن يوضع بين أيدي العامة والمفتين والباحثين.

ومما نود أن نستدعي الانتباه إليه، أن بعض العلماء أشار إلى جملة من قواعد نقد المتن، ومن أوائل من تصدوا لهذا ابن قيم الجوزية في كتابه المنار المنيف، بل إنه تحدث عن هذه القواعد، لاعتبار الناظر في متون الأحاديث، يستطيع أن يهكم عليها استنادا لهذه القواعد (تسع عشرة قاعدة)، دون الرجوع إلى الأسانيد، ولكنه اشترط لذلك، معرفة السنن، وكلام رسول الله صلى الله عليه وسلم حيث قال: "وسئلت: هل بمكن

$$
50
$$


معرفة الحديث المضبوط بضابط من غير أن ينظر في سنده؟ فهذا شؤال عظين القدر، وإنما يَعْلَمُ ذلك من تضلّع في معرفة السنن الصحيحة، واختلطت بلحمه ودمه، وصار له فيها ملكة، وصار له اختصاص شديد بمعرفة السنن والآثار، وعرفة سيرة رسول الله صلى الله عليه وسلم وهديه، فيما يأمر به، وبنهى عنه ويخبر عنه، ويدعو إليه ويحبه ويكرهه، ويشرعه للأمة، بحيث كأنه مخالط للرسول صلى الله عليه وسلم كواحد من أصحابه، فمثل هذا يعرف من أحوال الرسول الله صلى الله عليه وسلم - هديه وكلامه، وما يجوز أن يخبر به وما لا يجوز - ما لا يعرفه غيره. وهذا شأن كل متّع مع متبوعه، فإن للأخص به الحريص على تتبع أقواله وأفعاله من العلم مها، والتمييز بين ما يصح أن ينسب إليه وما لا يصح، ما ليس لمن لا يكون كذلك، وهو شأن المقلدين مع أئمتها يعرفون أقوالهم، ونصوصهم ومذاهبهم". 51 وقد أشار هو وغيره إلى بعض قواعد نقض المتن ومنها ركاكة ألفاظه، واشتماله على المجازفة في الثواب والعقاب وغيرها.

\section{الضابط الثاني :عرض السنة على القرآن}

لقد سبق أنْ أشرنا إلى جذرية علاقة السنة بالقرآن، وهذا الأمر بات واضحا، حتى صار الحديث فيه ضربا من التكرار، وإنما نود أن نؤكد هنا على أن هذه العلاقة الجذذرية بين شقي الوحي، ينبغي عدم بحاوزها، والغاية من تأكيدنا على أهمية عرض السنة على القرآن، أن نخرص على الوصول إلى أفضل الفهم وأحسنه للسنة، فربما كان لحديث مخصصا ما عممه القرآن، وربما كان مفصلا ما أجمله أو مقيدا ما أطلقه، أو موضحا لمعنى من المعاني، وهذا كله يقربنا للفهم الصحيح للسنة؛ ولا يتوقف أمر عرض السنة على القرآن عند هذا الحد، بل يتجاوز إلى إمكانية النظر في صحة متن الحديث أو ضعفه، وقد كان تعارض الحديث مع القرآن كافيا لدى أصحاب رسول الله صلى الله عليه وسلم لردّه، فهذا عمر بن الخطاب رد حديث فاطمة بنت قيس، أن زوجها طلقها آخر تطليقة، ولم يجعل لها النبي صلى الله عليه وسلم نفقة ولا سكنى، 52 فرده

51 ابن القيم الجوزية، المنار المنيف في الصحيح والضعيف، حلب مكتب المطبوعات الإسلامية، تحقيق الشيخ عبد الفتاح أبوغدة رمه الله، 
وقال" :لا ندع كتاب الله وسنة نبينا بقول امرأة لا ندري حفظت أم نسيت"، أشار عمر بكتاب الله إلى

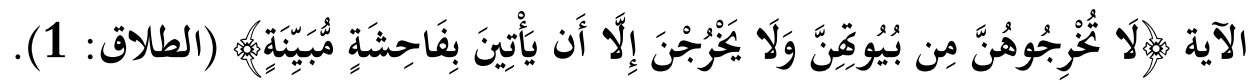

كما أن عائشة ردت حديث "إن الميت يعذب ببكاء أهله عليه، 53 لمخالفته لقوله تعالمى هوَلَا تَزْرُ

$$
\text { وَازِرَةُ وِزْرَ أُخرى }
$$

فمثل هذه النخالفة ينبغي أن تكون كافية في رد الحديث، في حال ثبوتا وعدم إمكانية الجمع أو التوفيق بين الآية والحديث، ذلك أن شِقَّيْ الوحي لا يمكن أن يتعارضا في النهاية وإن بدا ذلك في لحظة من اللحظات.

وما نود التحذير منه في هذا المقام التسرع والتوسع في دعوى تعارض الأحاديث مع الآيات، دون أن يكون لذلك أساس صحيح، كما فعل المعتزلة برد الأحاديث الصحيحة المستفيضة، في أثبات الشفاغة في الآخرة للرسول صلى الله عليه وسلم ولأنبياء والملائكة وصالحي المؤمنين، بحجة أن هذا يتعارض مع القرآن الذي نفى شفاعة الشافعين، ومن قرأ القرآن ولم يجد فيه إلا نفي (الشفاعة الشركيّة) التي كان يعتقدها

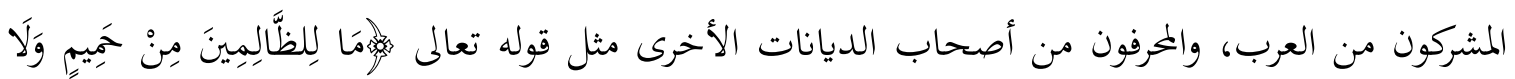
شَفِيعٍ يُطَاعُهُ (غافر : 18). وغير ذلك من الآيات كما أن القرآن أثبت الشفاعة بشرطين، أولما، أن تكون

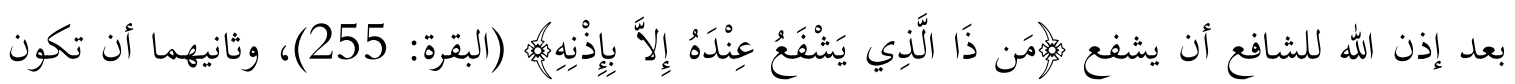

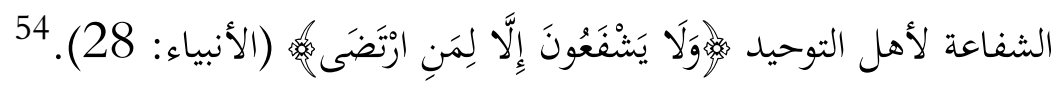

الضابط الثالث :عرض السنة على السنة سندا ومتنا

فكما أنه ينبغي عرض السنة على القرآن لأن ذلك يساهم في فهمها، ويساعد في التوثق من الحكم على الحديث، للعلاقة العضوية بين شقي الوحي، فإن عرض السنة على السنة من باب أولى، وما يتحدث عنه الباحثون من جمع الأحاديث الواردة في الموضوع الواحد يمثل جزءا من هذا العرض وليس هو تماما، ذلك كي كئ

$$
53 \text { } 54
$$


أن جزءا من مهمة جمع أحاديث الموضوع الواحد، ردّ متشاهها إلى محكمها، وحمل مطلقها على مقيدها، وتفسر عامها بخاصها، وبذلك يتضح المعنى المراد، ولا يضرب بعضها ببعض. 55

كما أن من غايات عرض السنة على بعضها، كشف علل الحديث من علل إسناد وعلل متن، كما أشرنا إليها سابقا والإدراج، والاضطراب، والقلب، والتصحيف، والتحريف. ومن غاياته أيضا التأكد من موافقة الرواية لما ورد في السنة من أحاديث أخرى من أحكام وأفهام وعدم معارضتها لها، ومن ثم تصحيح الرواية، وعدم الحكم عليها بالشذوذ.

وقد كان الصحابة رضوان الله عليهم يفعلون هذا فيما بينهم، فيعرضون روايات بعضهم على بعض.56 ومن لك ما ورد عن أبي بكر بن عبد الرحمن قال: سمعت أبا هريرة رضي الله عنه يقص، يقول في قصصه من أدرك الفجر جُجنبا فلا يصم، فذكرت ذلك لعبد الرمن لن الحارث، فأنكر ذلك، فانطلق عبد الرحمن وانطلقت معه، حتى دخلنا على عائشة وأم سلمة رضي الله عنهما، فسألمما عبد الرحمن عن ذلك، قال: فكلتاهما قالت: كان تابيي صلى الله عليه وسلم يصبح جنبا من غير حلم، ثم يصوم، قال: فانطلقنا حتى دخلنا على مروان والي المدينة في عهد معاوية، فذكر ذلك له عبد الرحمن، فقال مروان: عزمت عليك إلا ما ذهبت إلى أبي هريرة فرددت عليه ما يقول، قال: فجئنا أبا هريرة وأبو بكر حاضر ذلك كله، قال: فذكر له عبد الرحم، فقال أبو هريرة: أهما قالتهما لك؟ قال: نعم، قال: هما أعلم، ثم رد أبو هريرة ما كان يقول في ذلك إلى الفضل بن العباس، فقال أبو هريرة: سمعت ذلك من الفضل، ولم أسععه من النبي صلى الله عليه وسلم قال فرجع أبو هريرة عما كان يقول في ذلك. 57 فنحن نرى في هذا المقام كيف أسهمت رواية أمهات المؤمنين في تعديل رواية أبي هريرة، وما كان ذلك ليتضح لولا عرض السنة برواية أبي هريرة على السنة برواية أمهات المؤمنين.

$$
\begin{aligned}
& 55
\end{aligned}
$$

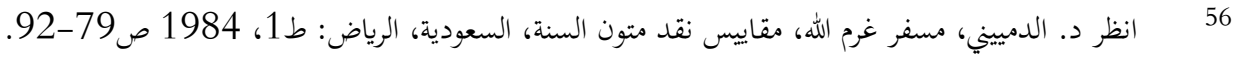

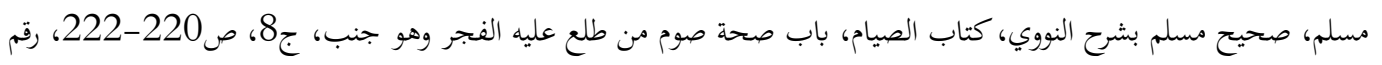


أما على صعيد الفهم الصحيح للسنة في ضوء بعضها، فإننا إذا نظرنا إلى حديث البخاري، الذي رواه في كتاب المزارعة من صحيحه، عن أبي أمامة الباهلي حين نظر إلى آلة حرث (محراث) فقال: سمعت رسول الله صلى الله عليه وسلم يقول: لا يدخل هذا بيت قوم إلا أدخله الله الذل، 58 نجد ظاهره يفيد كراهية الرسول للحرث والزراعة التي تفضي إلى ذل العاملين فيها، وقد حاول بعض المستشرقين استغلال هذا الحديث لتشويه موقف الإسلام من الزراعة، وهذا الظاهر يعارض نصوصا صريحة صحيحة أخرى، منها ما رواه الشيخان وغيرها: "ما من مسلم يغرس غرسا أو يزرع زرعا فيأكل منه طير أو إنسان أو بهيمة إلا كان له به صدقة"، 59 وغيره من النصوص. فأي عمل أفضل من هذا العمل، وأي حث على الزراعة أفضل من هذا الحث، كما أننا إذا نظرنا إلى الحديث الصحيح: "إذا تبايعتم بالعينة وأخذتم أذناب البقر، ورضيتم بالزرع وتركتم الجهاد، سلط الله عليكم ذلا لا ينزعه حتى ترجعوا إلى دينكم". 60 يتضح لنا بهذا الحديث أن المقصود بذلك الحديث (آلة المحراث) الإخلاد إلى الزراعة والدنيا والشؤون الخاصة وإهمال الواجبات ومنها الجهاد، وكل ذلك يؤدي إلى ذل الأمة. 61

هذا فضلا عن أن عرض السنة بعضها على بعض، يساعد في إدراك جملة من خصائص التشريع، ومن أبرزها التدرج، ومراعاة الواقع ومعالجته بما يناسب، كما في أحاديث ادخار الأضحية وغيرها.

ومما يتعلق بهذا الضابط المنهجي، أن نحذر من التوسع في رد بعض الأحاديث بدعوى معارضتها لأحاديث أخرى، تماما كما حذرنا من التوسع في دعوى معارضة السنة للقرآن، ولا بد هنا من الإشارة إلى أهمية أصول الجمع والترجيح بين الروايات التي يظهر منها التعارض، وأن القاعدة العامة أن "إعمال النص أولى من إهماله، فإن كان الجمع والتوفيق ممكنا فالأخذ به أولى، وأوجه الجمع في العادة كثيرة، كحمل العام على الخاص والمطلق على المقيد، والمجمل على المفصل، وتعدد مواقف وأقوال رسول الله في المسألة الواحدة،

$$
\begin{aligned}
& 58 \text { 5 } 58
\end{aligned}
$$

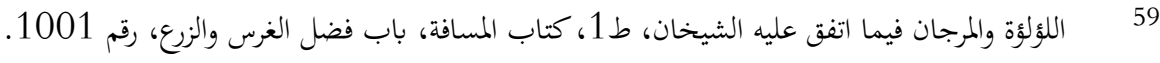

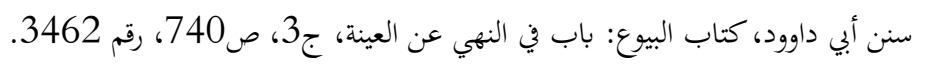

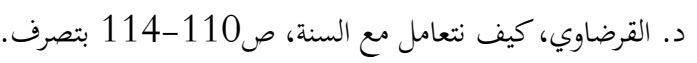


إذا ثبت التكرار ولم يكن ثمة تعارض". على أننا نحذر أيضا من التكلف في الجمع ولي أعناق النصوص. فإذا لم نتمكن من الجمع والتوفيق لجأنا بعدها إلى الترجيح.

\section{الضابط الرابع :عرض السنة على الحقائق الكونية والتاريخية والعلمية}

وهذا الضابط يكتسب أهميته من أن الحقائق التي نتحدث عنها اكتسبت وصف الحقيقة، ووصلت إلى درجة القطعية في الثبوت والتحقق، فإذا تم عرض السنة عليها وخالفتها مخالفة لا بجال لدفعها، فإننا لانملك إلا أن نرد تلك الرواية وإن صح سندها. وأساس ذلك ضرورة التوافق في القراءتَيْن بين قراءة الكون وقراءة الوحي، فكلاهما يهدي إلى الإيمان ولا تعارض بينهما في النهاية".

ومن ذلك ما روي عن الشيخين في حديث الإسراء قوله: "ليلة أسري بالنبي صلى الله عليه وسلم من

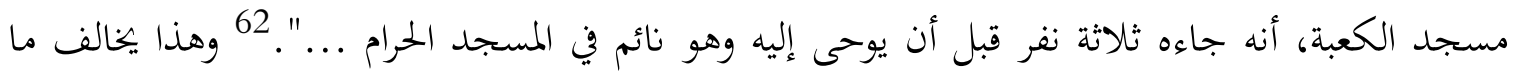
هو معروف عند جميع المسلمين أن الإسراء كان بعد البعثة، لا يشك في ذلك أحد منهم، وأدلته أكثر من أن تحصى. 63 أما فيما يتعلق بحقائق الكون فيؤكد ما ذهبنا إليه ما أكده رسول الله صلى الله عليه وسلم لأصحابه، عندما ظنوا أن الشمس قد كسفت لموت إبراهيم إبن النبي صلى الله عليه وسلم حيث قال "إن الشمس والقمر من آيات الله، وأغما ينخسفان لا تخسفان لموت أحد ولا لحياته". 64 ولذلك كان من الطبيعي أن يضعف ما ورد من رد الشمس لعلي وتأخير غروبها ليدرك الإمام علي صلاة العصر، كما أشار

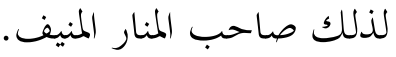

ولا يقل عن هذا شأنا مخالفة بعض الروايات للحقائق التي أثبتها العلم ولم تعد قابلة لنقض، ومن ذلك ما نسب إل عائشة رضي الله عنها من قولها: "كنّ نساء بني إسرائيل يتخذن أرجلا من خشب يتشرفن للرجال في المساجد، فحرم الله عليهن المساجد، وسلطت عليهن الحيضة" رواه عبد الرزاق عن ابن مسعود بإسناد صحيح وعنده عن عائشة نهوه. وهذه الرواية عن عائشة مما لا يقال من قبل الرأي، ولذلك فقد

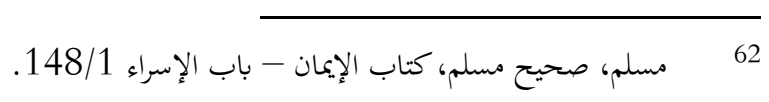

الدميني، مقاييس نقد متون السنة، صنابعان 184-185. وانظ د. الإدلبي صلاح الدين، منهج نقد المتن عند علماء الحديث، دار الآفاق

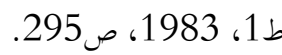

$$
\text { مسلم، صحيح مسلم، كتاب الكسوف، باب صلاة الكسوف، رقم } 1983 .
$$


يطلق عليها، أن لها حكم المرفوع، كما قال ابن حجر. 65 ولا يخفى مخالفة هذا لما أثبته الطب والعلم من ارتباط الحيض بطبيعة المرأة وخصائصها البيولوجية، بل إن عائشة رضي الله عنها روت أنه عندما سألها رسول الله في الحج "أَنْفِستبِ؟ قالت: نعم، قال: إن هذا شيئ كتبه الله على بنات آدم". 66

على أنه ينبغي التنبيه هنا أيضا على إمكانية حمل بعض الروايات على المجاز لا على حقيقة اللفظ، ومن تَمَ فلا داعي للتسرع في رد الرواية في أول وهلة لمجرد أن يتبادر للذهن تعارضها مع شيئ من هذه بلى الحقائق. ومن ذلك مثلا "حديث النيل والفرات وسيحون وجيحون من أهار الجنة"، 67 حيث بادر بعضعم إلى رده، بحجة مخالفته للحقيقة والواقع إذ إن منابع هذه الأغار معرفة لكل درس، فهي نابعة من الأرض وليست من الجنة.

"يقول ابن حزم معقبا على هذا الحديث، وحديث "بين بيتي ومنبري روضة من رياض الجنة":68 "هذان الحديثان ليس على ما يظن أهل الجهل من أن الروضة مقتطعة من الجنة، وأن هذه الأغار مهبطة من الجنة، هذا باطل وكذب، ثم ذكر ابن حزم أن معنى كون تلك الروضة من الجنة إنما هو لفضلها، وأن الصلاة فيها تؤدي إلى الجنة، وأن تلك الأهار لبركتها أضيفت إلى الجنة ..." ويقول: فوضح البرهان من القرآن ومن ضرورة الحس على أها ليست على ظاهرها.

هذا هو موقف ابن حزم المعروف بظاهريته وتمسكه بحرفية النصوص إلى حد الجمود، ومع هذا لم يسغ عنه أن تحمل هذه النصوص على ظواهرها، فإنما يظن ذلك أهل الجهل كما قال. 69

على أننا نحذر أيضا من التكلف والتوسع في التأويل المجازي بما لا يتحمله النص ولا تسعه اللغة. كتأويل السحور بمعنى الاستغفار في حديث تسحروا فإن في السحور بركة. 70

$$
\begin{aligned}
& 65
\end{aligned}
$$

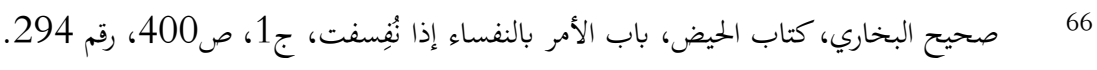

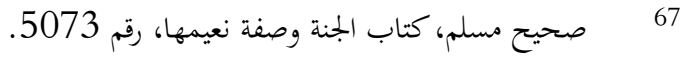

$$
\begin{aligned}
& 68 \\
& 69 \text { } 70 \\
& \text { 70 }
\end{aligned}
$$




\section{الضابط الخامس :عرض السنة على المقاصد}

مما لم يعد خافيا على أحد، أن غاية الشريعة تحقيق مصلحة الإنسان وسعادته في الدارين، وقد كانت جملة أحكام الإسلام ونظمه، هادفة إلى جملة من الغايات والمقاصد، تمثلت فيما أشار إليه العلماء من الضروريات، والحاجيات والتحسينات، التي يشكل الحفاظ على النفس والعقل والدين والمال والنسل محمورها جميعا، إن جملة أحكام الإسلام وتشريعاته تكاد تتمحور حول هذه المقاصد التي تحقق مصلحة الإنسان، حتى قال أهل العلم: حيثما وجدت المصلحة فثما شرع الله. وهكذا فمن الطبيعي أن يكون فهم السنة، مقتربا بأكبر درجة ممكنة من تحقيق هذه المصلحة في ضوء تلك المقاصد، وفي ضوء فقه الأولويات الموازنات، ومراعاة المصلحة العامة والمصلحة الخاصة في ضوء ذلك الفقه على أننا ننبه إلى ضرورة تقليب الأمر ودراسته جيّدا في محاولة التقريب بين فهم النص والمصلحة، ذلك أن دراسة هذا الأمر تحتاج في كثير من الأحيان، إلى معرفة ما وراء الظواهر ودراسة المآلات، لأن الإنسان في مقام البحث عن المصلحة، ربما يغلب عليه التعجل والتسرع في قطف الثمار، فيسارع في اعتبار المصلحة في أمر ما، ويتكشف له بعد مدة من الزمن أن المصلحة كانت في غيره. ولعل جزءا من الحل لهذا الإشكال، اللجوء إلى التفكير الجمعي، والاجتهاد المؤسسي، بعيدا عن الاجتهاد الفردي المتعجل، وهذا يتطلب بذل الجهد الكبير في إنضاج فقه الموازنات والأولويات وتأصيله، وبناء قواعده بشكل معاصر، يتلاءم مع تطورات هذا الزمان وواقعه.

وفي ضوء هذا الفهم المقاصدي، نستطيع أن نبين وجه ترجيحنا لفهم من قالوا بجواز إخراج صدقة الفطر بالقيمة، دون الوقوف عند حرفية الحديث. ذلك بأن الغاية من هذه الصدقة تحقيق مصلحة الفقير، والقول بجواز الإخراج بالقيمة أقرب لتحقيق تلك المصلحة. ولا سيّما في ضوء اختلاف الظروف من بلد إلى آخر، وعدم توفر الأصناف الواردة في الحديث بكميات كافية في بعض البلدان الإسلامية، فضلا عن مدى احتياج الفقير لتلك الأصناف من الأطعمة، وفي ضوء هذا السياق يمكننا أن نفهم أيضا قول النبي صلى الله عليه وسلم "الأئمة من قريش"، 71 فإن ظاهر هذا الححديث، لأن النبي صلى الله عليه وسلم يريد حصر الإمامة العظمى في قريش، لكنّ الناظر في هذا الحديث في ضوء مقاصد الشريعة وتحقيق مصالح المسلمين، يفهم

$$
71 \text { الإمام أمد، المسند ج129/3، 183. ج421/4، وانظر فتح الباري، ج13، ص113-119. }
$$


الحديث فهما آخر، حيث إن الإمامة قيادة للمسلمين في شتى منحي الحياة، ولا شك في أن الأكثر تحقيقا لمصلحة المسلمين أن يتولى هذا الأمر من كان يمتلك الكفاءة والخبرة الكافية لذلك، سواء كان من قريش أو كان من غيرها. ولعل ذكر قريش في هذا المقام، إنما جاء لأن تركيز الكفاءة في ذلك الزمان فيهم أكثر من غيرهم، لموقعهم بين العرب وأثرهم آنذاك، أم اليوم فمن أين غميز القرشي من غيره؟ ثم كيف ستكون النظرة إلى النظام السياسي الإسلامي إذا بقي علماؤنا مصرين على الفهم الظاهري للحديث. إنها عين التعصب للقبلية والقوم. وأين ذلك من الشورى، وحرية الإختيار والبيعة؟ وأين ذلك من تحقيق مقاصد الشريعة برعاية مصالح المسلمين؟ ولذلك قال الخوارج وطائفة من المعتزلة: "يجوز أن يكون الإمام غير قرشي، وإنما يستحق الإمامة من قام بالكتاب والسنة، سواء أكان عربيا أم عجميا". 72 وعليه فإن الإمامة للأكفأ، ويمكن اعتبار الإمامة لقريش شرطا مرجحا أو هامشيا، لكن ليس على حساب الكفاءة والقدرة وتحقيق مصلحة المسلمين.

\section{الضابط السادس :فهم السنة في سياقها الزمني الواقعي الذي وردت به}

نخطئ كثيرا حين نحاول فهم السنة النبوية منبة عن السياق الذي وردت فيه، سواء كان ذلك زمانيا أو واقعيا، ذلك أن مراعاة السياق الذي رويت خلاله السنة، يسهم كثيرا في دقة توجيه البوصلة نحو الفهم السليم للسنة، ومما يرتبط بهذا الأمر، الاطلاع على أسباب ورود الحديث، وهذا الأمر في غاية الأهمية بالنسبة إى السنة، وبنفس المستوى من أهمية أسباب النزول بالنسبة إلى فهم الآيات، ومما يرتبط بهذا الأمر أيضا مراعاة طبيعة الألفاظ الواردة في النصوص، ودلالاتا المفاهمية في الزمان الذي وردت به، ولهذا الأمر الأثر الكبير في حسن فهم النص وتنزيله المناسب في واقعنا المعاصر، وقد نبه الإمام الغزالي على تبدل الأسماء والمصطلحات بين زمان وأزمان فقال: "اعلم أن منشأ التباس العلوم المذمومة بالعلوم الشرعية، تحريف الأسامي المحمودة وتبديلها، ونقلها بالأغراض الفاسدة إلى معان غير ما أراد السلف الصالح والقرن الأول، وهي خمسة ألفاظ: الفقه والعلم والتوحيد والتذكير والحكمة، فهذه أسام محمودة، والمتّصفون بها أرباب المناصب في الدين، ولكنها نقلت آن إلى معان مذمومة، فصارت القلوب تنفر عن مذّة من يتصف بمعانيها، لشيوع إطلاق هذه الأسامي عليهم"، 73 ومما بحدر الاشارة إليه في هذا المقام تبدل مدلولات كلمة

$$
\begin{aligned}
& 72 \\
& 73 \text { القرضاوي، كيف نتعامل مع السنة، ص182-183 صل18. }
\end{aligned}
$$


التصوير مثلا، حيث يقع الكثيرون في الخطأ عندما يسحبون ما جاء من أحاديث في شأن التصوير، على التصوير الفوتوغرافي اليوم، مع أن المتأمل جيدا، يجد أن التصوير بالكاميرا لم يكن موجودا في عهد النبي صلى الله عليه وسلم ومِن تُمَ فلا يدخل في دلالات النصوص الواردة في التصوير، هذا من جهة، ومن جهة أحرى فإن كلمة التصوير كانت دلالاتما مباشرة على ما يسمى اليم بالنحت، وتصوير الأشياء مجسمة بنحتها، سواء من الحجر أو من الخشب أو غيره، فتسميه التصوير لتبدل دلالاته عبر الزمن نختا، لا ينفي حرمته، فيما يتعلق بتجسيم ما نفخت فيه الروح وتصوريها (أي نختها). كما أنه لا يدخل التصوير الفوتوغرافي ضمن ذلك المفهوم ليأخذ حكمه.

يقول الشيخ محمد الغزالي - رحمه الله - وقد استند إلى هذا الضابط، في نظرته إلى حديث النبي صلى الله عليه وسلم في ولاية المرأة حيث قال: "وقد تأملت في الحديث المروي في الموضوع مع أنه صحيح سندا ومتنا (يعني حديث ما أفلح قوم ولوا أمرهم امرأة) ولكن ما معناه؟ الدين وثني، والأسرة المالكة لا تعرف شورى، ولا تحترم رأيا يخالفا، والعلاقات بين أفرادها بالغة السوء، قد يقتل الرجل أباه أو إخوته في سبيل مآربه والشعب خانع منقاد، وكان في الإمكان، وقد اغزمت الجيوش الفارسية وأخذت مساحة الدولة تتقلص، أن يتولى الأمر قائد عسكري يُوقِف سيل الهزائم، لكن الوثنية السياسية جعلت الأمة والدولة ميراثا لفتاة لا تدري شيئا، فكان ذلك إيذانا بأن الدولة كلها إلى ذهاب، في التعليق على هذا قال النبي الحكيم كلمته الصادقة، فكان وصفا دقيقا للأوضاع كلها. لول أن الأمر في فارس شورى ... لكان هناك تعليق آخر على الأوضاع القائمة". 74 وهذا السبب الذي استند إليه الغزالي في فهمه للحديث، وأن النبي صلى الله عليه وسلم قاله إخبارا عن الفرس، لم يكن متخيلا أو افتراضيا. بل ورد ذكره في النص نفسه عن أبي بكرة قال: لما بلغ رسول الله صلى الله عليه وسلم: أن أهل الفرس قد ملّكوا عليهم أهل كسرى قال: لن يفلح قوم ولوا أمرهم امرأة.

وهذا النظر في سبب الورود يسهم كثيرا في توضيح المقصود بالرواية وتصويب الفهم لها. ولعل الأمر يتضح أكثر إذا أشرنا إلى "اختلاف العلماء في مدلول حديث"الماء طهور لا ينجسه شيء"، فمنهم من رأى

$$
\begin{aligned}
& 74
\end{aligned}
$$

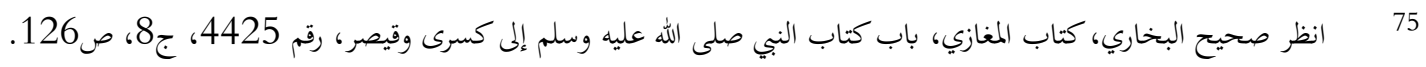


أن اماء طهور قليلا كان أو كثيرا، ما لم تتغير أوصافه، ومنهم من رأى أنه ينجس بالنجاسة لإن كان قليلا تغير أو لم يتغير، ولا تضره إن كان كثيرا إلا إذا تغيّر، والناظر في هذا الحديث وسبب وروده سينتفي عند مبرر الخلاف، ذلك أن أبا سعيد الخدري يقول: مررت بالنبي صلى الله عليه وسلم وهو يتوضأ من بئر بضاعة، فقلت: أتتوضأ فيها وهي يطرح فيها ما يكره من النتن؟ فقال: الماء طهور لا ينجسه شيء.76 وبئر بضاعة هذه كانت تقع في حدود الأرض، وأن السيول كانت تكسح الأقذار من الطرق والأقنية وتحملها وتلقيها فيها، وكان الماء لكثرته لا يؤثر فيه وقوع هذه الأشياء ولا يغيره. 77

\section{الضابط السابع :حسن تنزيل السنة على الواقع}

من المعلوم أن مقتضى صلاحية القرآن والسنة لكان زمان ومكان، يتريب عليه تطور فهم النص تبعا للواقع والزمان واختلاف الظروف، والقاعدة المشهورة لدى العلماء "لا ينكر تغير الأحكام بتغير الأزمان"، إنما تنبني على تغير فهم النصوص وتطوره تبعا للظروف والوقائع، مما يتيح سقفا معرفيا للاحقين لم يتح مثله للسابقين، ومراعاة الوافع والظرف الذي يحياه الناس، ليس ضربا مبتدعا في التعامل مع السنة النبوية. فقد سبق بهذا الصحابة رضوان الله عليهم، ومن ذلك موقف كل من عثمان بن عفان من ضالة الإبل، حيث أمر بتعريفها ثم تباع، فإذا جاء جاء صاحبها أعطي ثمنها. وكذا علي بن أبي طالب، إلا أنه رأى التقاطها والإنفاق عليها من بيت المال، حتى إذا جاء ربها أعطيت له. 78 وقد كان لهما هذان الموقفان رغم في النبي صلى الله عليه وسلم حين سئل عنها، عن التقاطها، وقال: "مالك ومالها؟ تدعها فإن معها حذاءها وسقاءها، ترد الماء، وتأكل الشجر حتى يجدها ربها". 79 وما ذلك إلا لتغيّر الظروف والواقع بين وقت سؤال الرسول عنها وبين زمان عثمان وعلي.

ويدخل في هذا السياق ما بني من النصوص على عرف زمني كان قائما في عصر النبوة، ثم تغير في عصرنا، وعلماء الفقه يعرفون في هذا الموضوع رأي الإمام أبي يوسف في الأصناف الربوية التي جاء بها

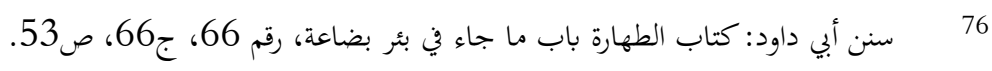

$$
\begin{aligned}
& 77 \text { } 78 \\
& 7878 \\
& 79 \text { } 79 \text { البخاري، صحيح البخاري، كتاب العلم باب الغضب في الموعظة، رقم 91، 133، ج1، ص186. }
\end{aligned}
$$


الحديث النبوي" البر بالبر، كيلا بكيل، مثلا بمثل"، وكذلك الشعير، والتمر، والملح، أما الذهب والفضة فقال فيهما "وزنا بوزن" فأبو يوسف يرى أن اعتبار ما ذكر من الأصناف مكيلا أو موزونا بني على العرف، فإذا تغير العرف وأصبح التمر أو الملح مثلا يباع بالوزن - كما في عصرنا - وجب العمل بما صار إليه العر ئر فالجديد، فيجوز بيع التمر والملح مثلا بالتمر والملح مزنا متساويا وإن تفاوتا كيلا". 80

ومن بعد ذلك ما جاء في منع المرأة من السفر إلا ومعها محرم، 81 حيث إننا إذا أردنا أن نحسن تنزيل هذا النص على الواقع فإنه ينبغي علينا مراعاة التطور الذي حصل في واقع السفر وتنقل المرأة، وانعكاس ذلك على ما تشعر به المرلأة من الأمان، حيث بات بإمكان المرأة أن تسافر في وسائل المواصلات المتطورة، مع عشرات من الركاب، دون أن تخشى على نفسها شيئا كثيرا، إذ يغلب على الظن في كثير من المواطن شعورها بالأمان، ويؤيد اعتبار هذه العلة في منعها من السفر فيما ورد من أحاديث، ما ورد في حديث عدي بن حاتم مرفوعا عن البخاري:حيث قال لعدي: "فإن كانت بك حياة لنزين الظغينة ترحل من الحيرة حتى تطوف بالكعبة لا تخاف أحدا إلا الله". 82 فنحن إذا أردنا أن نبتعد عن واقعنا المعاصر، ومنع المرأة من كل سفر إلا مع زوج أو محرم، فسنحول بينها وبين العمل والدراسة وغير ذلك. ومثل هذا النظر إلى الواقع، يمكن أن يقال فيما يتعلق بادخار لحوم الأضاحي، أو النهي عنه، تبعا لحال المجتمع من الفقر أو الغنى، وكذا في مقدار الديّة، وإخراج زكاة الفطر كما أشرنا إليه سابقا، وغير هذا الكثير الكثير. على أننا نود أن نؤكد في هذا المقام، أنه ليس المقصود بقولنا مراعاة الواقع، أن نلوي أعناق النصوص، ونحملها ما لا تحتمل، لنراعي واقعنا، وإنما المقصود إحسان فهم الواقع، وإحسان تنزيل النص عليه، بعد إحسان فهم النص أيضا في ضوء القواعد المتبعة.

\section{خلاصة البحث وتوصياته:}

كان هذا البحث محاولة من الباحث لاستدعاء انتباه العلماء إلى خطورة ما تتعرض له السنة من خلل في منهج التعامل معها، مثل الفصل بين أجزاء الوحي ومفرداته، والفصل بين قراءة السنة وقراءة الكون،

$$
\begin{aligned}
& 80
\end{aligned}
$$

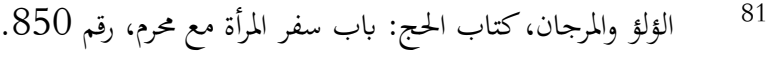

$$
\begin{aligned}
& 82
\end{aligned}
$$


والفصل بين السنة والرؤية الكلية الشمولية المقاصدية للشريعة الإسلامية، وعدم التمبيز بين ما كان من السنة محلا للتشريع، وما لم يكن، والتسرع في ردّ الأحاديث، وعدم استكمال شروط نقد الرواية، والفصل بين الفقه والأحاديث.

وقد دعا الباحث إلى ضرورة تجنب مظاهر الخلل آنفة الذكر، عند التعامل مع السنة المشرفة. واعتبر أن الاعتداءات المنهجية على السنة، في هذه الزمان لا تقل خطرا عن محاولات الوضع والدس والتحريف، التي تعرضت لها السنة في عصر الرواية.

وقد حاول الباحث أن يقدّم رؤية منهجية للتعامل مع السنة النبيّة، مقترحا بعض الضوابط المنهجية، لتجاوز الحلل المنهجي في التعامل مع السنة النبوية، وذلك مثل التوثق من الحديث سندا ومتنا وفق القواعد والشروط المحددة من قبل العلماء، وعرض السنة على القرآن الكرين، وعرض السنة على السنة سندا ومتنا، وعرض السنّة على الحقائق الكونيّة والتاريخيّة والعلمية، وعرض السنّة على المقاصد، وفهم السنة في سياقها الزمني الواقعي الذي وردت به، وحسن تنزيل السنّة على الواقع.

ويرى الباحث في ضوء بكثه هذا أن بقاء المنهجيات القائمة في زماننا هذا سيحيد بالسنة عن أداء دورها في البناء الفكري والمعريف والحضاري للأمة، وأنه لا بد من التزام مناهج وضوابط تعيد للسنة دورها التوجيهي والبنائي المعرفي والحضاري في الأمة، وأن علماء السنة لا يستطيعون وحدهم النهوض هذا الدور، بل هم بأمسّ الحاجة إلى علماء آخرين من أصحاب التخصصات المختلفة. وقد حاول الباحث أن يشكل من الضوابط آنفة الذكر، إطارأ عاما يدخل منه الباحثون إلى الحقول العرفية في السنة النبوية، لتتجاوز السنّة بذلك الدور التشريعي، إلى بناء المعرفة والحضارة.

وبناء عليه فإن الباحث يدعو إلى تواصل جهود علماء الأمة ومفكريها (من علماء السنة وغيرهم)، في محاولة الإجابة على ما طرح هذا البحث من قضايا وإشكالات، وإعادة قراءة السنة النبوية، والنظر في أثر العلوم الحديثة وتطورها، في تطور فهمنا للسنّة النبوية، والتوصل إلى جملة من علوم الكون التي توصل إلى مثلها علماء الغرب وغيرهم. ويدعو الباحث إلى مراجعة المناهج التعليمية في المدارس والجامعات، بما يكفي لاحياء الاهتمام بالسنة النبوية، لأداء الدور المنشود المشار إليه، ولا سيّما برامج الدراسات العليا والخطط 
الأكاديمية. كما يدعم الباحث إلى الإهتمام بجملة من البحوث والدراسات المتعلقة بما أثاره هذا البحث، كمحاولات حصر ضوابط أخرى في التعامل مع السنة، وإعادة تصنيفها، والتوسع في الدراسات التطبيقية على هذه الضوابط، بلاإضافة إلى الإهتمام الخاص بعلم العلل في الإسناد والمتن، والتركيز على نقد المتن والعلوم المتعلقة به، فضلا عن إجراء الدراسات على أثر تطور العلوم، وتغيير الظروف زمانيا ومكانيا، على فهم السنة والتعامل معها.

والأمل كبير بأن يكون هذا البحث قد أسهم في إثارة القضايا المهمة المتعلقة بالسنة، وبالتأكيد ثمة كثير غيرها، يحتاج إلى مزيد إثارة واهتمام، وهكذا كان طريق العلم دائما، زاخرا بالجهود المتواصلة من طلبة العلم والباحثين للوصول إلى أحسن الفهم. و الله نسأل السداد والتوفيق. 